\title{
Combined effect of durian (Durio zibethinus Murr.) and $\beta$-glucan on glycaemic response and food intake in male rats
}

\author{
A Aziz, N.A, *Mhd Jalil, A.M. and Roslan, S. \\ School of Nutrition and Dietetics, Faculty of Health Sciences, Universiti Sultan Zainal Abidin (UniSZA), \\ 21300 Kuala Nerus, Terengganu, Malaysia
}

\author{
Article history: \\ Received: 28 April 2020 \\ Received in revised form: 10 \\ June 2020 \\ Accepted: 4 July 2020 \\ Available Online: 13 August \\ 2020
}

\section{Keywords:}

Durian,

Total polyphenols content, $\beta$-Glucan,

Glucose response,

Food intake

\section{DOI:}

https://doi.org/10.26656/fr.2017.4(6).198

\begin{abstract}
Durian (Durio zibethinus Murr.) is notorious for its stench. However, durian has a smooth texture and creamy taste, and is rich in macronutrients, bioactive compounds, and volatile compounds. These qualities could be useful in combination with other food components such as $\beta$-glucan. $\beta$-Glucan is a type of soluble fibre that has been approved by the European Food Safety Authority (EFSA) for beneficially reducing the postprandial glucose response. The aims of this study were to determine the total polyphenol content in durian and to determine the combined effects of durian and $\beta$-glucan on glycaemic response and food intake in rats. The total polyphenols content in the durians (variety D24) was 131.40 (22.20) mg GAE/100 g fresh weight. Durian significantly reduced ( $p<$ 0.05 ) postprandial glucose responses at $15,30,60$, and 120 mins compared with control. A combination of durian and $\beta$-glucan significantly $(p<0.05)$ reduced glucose responses at 30,60 and 90 mins compared with control. A combination of durian and $\beta$-glucan significantly $(p<0.05)$ reduced glucose responses at 120 mins compared with control and $\beta$-glucan. Food intake of the durian $+\beta$-glucan group was significantly $(p<0.05)$ lower than the control, durian and $\beta$-glucan groups. This study suggests that a combination of durian and $\beta$-glucan potentially reduces glycaemic response and food intake but this needs to be tested in humans.
\end{abstract}

\section{Introduction}

Durio zibethinus Murr., commonly known as durian, is widely dubbed the 'King of Fruits'. Recent research has shown that durian is rich in macronutrients (carbohydrate and sugar), bioactive compounds and dietary fibre (A Aziz and Mhd Jalil, 2019). Although durian is rich in bioactive compounds, its use for the development of functional food is still limited. Durian features in a few local Malaysian condiments and delicacies such as serawa and lempuk (Mat Amin et al., 2007; Ho and Bhat, 2015) but their high salt or sugar content limits their health benefits. Durian has cholesterol-lowering properties when fed to hypercholesterolaemic rats (Leontowicz et al., 2008). Leontowicz et al. (2011) demonstrated antiatherosclerotic properties of durian in rats. A diet comprising $5 \%$ durian by weight reduced total lipid and low-density lipoprotein cholesterol compared with a control diet (Leontowicz et al., 2011).

Durian is rich in sugar and fat, and hence energydense (A Aziz and Mhd Jalil, 2019). The total sugar concentration of different durian varieties ranges from 3 $\mathrm{g}$ to $20 \mathrm{~g}$ per $100 \mathrm{~g}$ fresh weight in Malaysian, Thai and Indonesian varieties (A Aziz and Mhd Jalil, 2019). Despite the high sugar content, durian supplementation reduced post-prandial glucose and insulin responses in healthy volunteers compared with watermelon, papaya and pineapple (Robert et al., 2008). The same study showed that the glycaemic index of durian was significantly lower than that of other tropical fruits. This could be due to the presence of polyphenols, potassium or fat. Our previous review showed that durian is rich in polyphenols with $374 \mathrm{mg}$ gallic acid equivalent, $601 \mathrm{~g}$ potassium, and $5 \mathrm{~g}$ fat per $100 \mathrm{~g}$ fresh weight (A Aziz and Mhd Jalil, 2019). The fat content is important: high energy density meals with a high fat load significantly reduced gastric emptying by $22 \%$ compared with low energy density, high-protein load meals (LuscombeMarsh et al., 2013). Delayed gastric emptying is associated with a lower glycaemic response after a meal and vice versa (Marathe et al., 2019). The rate of gastric emptying depends on factors such as the food matrix (liquid vs solid) and macronutrient composition (fat, 
protein and carbohydrate) (Phillips et al., 2015). The presence of dietary components such as soluble dietary fibres (pectin, guar gum, polydextrose and $\beta$-Glucan) reduced the gastric emptying rate compared with control (Salleh et al., 2019).

$\beta$-Glucan occurs in cereal grains. It is contained in oat and barley endosperm cell walls (Delaney et al., 2003; Theuwissen and Mensink, 2008). B-Glucan is a functional ingredient with numerous health benefits, e.g. increased perceived satiety, reduced food intake and reduced postprandial glucose response (Salleh et al., 2019). Previous studies showed $\beta$-glucan beneficially reduced glucose response when prepared in bread and biscuits (Kerckhoffs et al., 2003; Hartvigsen et al., 2014). $\beta$-Glucan is not digestible in the stomach but is metabolised by intestinal bacteria into short-chain fatty acids (SCFA) such as acetate, propionate and butyrate (Nishimura et al., 2017). SCFAs, especially propionate, have been implicated in appetite regulation and might reduce body weight through stimulation of gut hormones peptide YY (PYY) and glucagon-like peptide 1 (GLP-1) (Chambers et al., 2015). Barley $\beta$-glucan increased gut hormones PYY and GLP-1 and subsequently reduced food intake and improved insulin sensitivity in mice (Miyamoto et al., 2018). It has been suggested that the increased levels of gut hormones PYY and GLP-1 were due to the increased levels of acetate, propionate and butyrate (Miyamoto et al., 2018). Huang et al. (2011) showed an increased level of cholecystokinin (CCK) after $\beta$-glucan supplementation in mice. These findings suggest that $\beta$-glucan could beneficially reduce postprandial blood glucose response and reduced food intake. $\beta$-Glucan could hence be used as an active ingredient for the development of functional food in conjunction with other food components such as durian. This study aimed to determine the effect of combining $\beta$ glucan and durian in a liquid formulation on food intake and blood glucose response.

\section{Materials and methods}

\subsection{Total polyphenols content}

\subsubsection{Extraction}

Fresh durian sample (D24 variety, $5 \mathrm{~g}$ ) was weighed and mixed with $250 \mathrm{~mL}$ of 70:30 acetone: water $(\mathrm{v} / \mathrm{v})$. The mixture was mixed for 3 mins in a laboratory blender at medium speed. The mixture was then placed in a shaking water bath at $20^{\circ} \mathrm{C}$ for 60 mins. Finally, an aliquot $(7.5 \mathrm{~mL})$ was centrifuged, at $4^{\circ} \mathrm{C}$, at $4000 \mathrm{rpm}$ for 10 mins. The supernatant was used for total polyphenols analysis (Lutz et al., 2015).

\subsubsection{Determination of total polyphenols content}

Durian extract $(2.5 \mathrm{~mL})$ was mixed with $1.25 \mathrm{~mL}$ of Folin-Ciocalteu reagent, $3.75 \mathrm{~mL}$ sodium carbonate and $17.5 \mathrm{~mL}$ distilled water. The mixture was incubated for 30 mins at $37^{\circ} \mathrm{C}$. The absorbance was measured at $765 \mathrm{~nm}$ against reagent blank. Gallic acid in the range of $0-100 \mu \mathrm{g} / \mathrm{mL}$ was used as an external standard. Total polyphenols content is expressed as $\mathrm{mg}$ gallic acid equivalents (GAE)/g fresh weight (Singleton et al., 1999).

\subsection{Preparation of formulations (durian and $\beta$-Glucan)}

Durian (variety D24) was purchased from a local supplier (Chabang Tiga, Terengganu, Malaysia). The dose of durian formulations was calculated according to Robert et al. (2008). Fresh durian pulp (193.0 g) was needed to prepare standardized formulation containing 50 $\mathrm{g}$ of available carbohydrate. The formulations were converted to a rat dose using a human-equivalent dose (HED) (Nair and Jacob, 2016). HED was calculated as follow: $193.0 \mathrm{~g}$ durian pulp/ $60 \mathrm{~kg}^{*}=3.23 \times 6.2=20.03$ $\mathrm{g} / \mathrm{kg}$ (*based on $60 \mathrm{~kg}$ weight of human) (USFDA, 2005). The conversion coefficient of 6.2 was used to account for differences in body surface area between rats and human (Nair and Jacob, 2016).

The dose of the formulations for $\beta$-glucan was followed according to European Food Safety Authority (EFSA). EFSA recommends $4 \mathrm{~g}$ of $\beta$-glucan with $30 \mathrm{~g}$ of available carbohydrates to reduce glycaemic response (EFSA, 2011). After considering the product purity, $20 \mathrm{~g}$ of $\beta$-glucan (20\% purity) (Biogrow Oat BG22, Selangor, Malaysia) was used to match the EFSA recommendation. The formulations were converted to a rat dose using a human-equivalent dose (HED) (Nair and Jacob, 2016). HED was calculated as follow: $20.0 \mathrm{~g} \mathrm{BG} 22 / 60 \mathrm{~kg} *=$ $0.33 \times 6.2=2.05 \mathrm{~g} / \mathrm{kg}$ (*based on $60 \mathrm{~kg}$ human) (USFDA, 2005). Again, the conversion coefficient of 6.2 accounts for differences in body surface area between rats and human (Nair and Jacob, 2016).

\subsection{Animal preparation}

Ethical approval was obtained from UniSZA Animal and Plant Research Ethics Committee (UAPREC), Universiti Sultan Zainal Abidin (UAPREC/04/010). Thirty-two male Sprague-Dawley rats (120 - $150 \mathrm{~g}$ initial weight) were purchased from local research animal supplier (Chenur Supplier, Kajang, Selangor, Malaysia). The rats were acclimatized at room temperature (24-28 C) under a standard light/dark cycle and were allowed to normal diet and water.

The rats were randomly separated to four groups as follows: control $(n=6,2.32 \mathrm{~g} / \mathrm{kg}$ Glucolin $+20 \mathrm{~mL} / \mathrm{kg}$ 
$0.03 \% \mathrm{CMC})$; durian ( $n=6,19.20 \mathrm{~g} / \mathrm{kg}$ durian); $\beta$-Glucan $(n=7,2.00 \mathrm{~g} / \mathrm{kg} \beta$-Glucan $)$ and durian $+\beta$-glucan $(n=8$, $19.20 \mathrm{~g} / \mathrm{kg}$ durian $+2.00 \mathrm{~g} / \mathrm{kg} \beta$-Glucan). Table 1 shows the composition of the four formulations. Rats had unrestricted access to drinking water and were fed a normal chow diet (Altromin, Lage, Germany). Bodyweight was recorded at baseline and food intake was measured before (baseline) and for up to $24 \mathrm{hrs}$.

Table 1. Composition of different formulations used in the study

\begin{tabular}{|c|c|c|c|c|}
\hline & 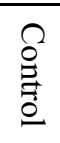 & $\begin{array}{l}\underset{\Xi}{\Xi} \\
\stackrel{\Xi}{\Xi}\end{array}$ & 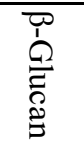 & 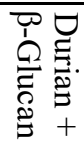 \\
\hline Glucolin (g) & 2.6 & - & - & 2.5 \\
\hline Durian aril (flesh) $(\mathrm{g})$ & - & 19.8 & 19.8 & - \\
\hline BG22 powder (g) & - & - & 4.3 & 4.3 \\
\hline
\end{tabular}

All formulations contain similar total sugar and were prepared in $0.03 \%$ Carboxymethyl Cellulose (CMC) as the vehicle.

\subsection{Postprandial glycaemic response}

Postprandial glycaemic response was determined at 0 to 120 mins and incremental area under the curve (iAUC) calculated. Different formulations were administered after an overnight fast $(12 \mathrm{hrs})$ by gastric intubation. Fasting ( $0 \mathrm{~min}$ ) blood was obtained from tail snip and thereafter at 15, 30, 60, 90 and 120 mins after supplementation. Glucose levels were determined using a glucometer (Accu-Chek, Roche Diagnostics, Switzerland). Incremental area under the curve (iAUC) was measured using a calculator courtesy of Dr Thomas Wolever, University of Toronto, Canada.

\subsection{Statistical analysis}

Data were analysed using IBM SPSS Statistics for Windows (version 22.0) (IBM Corp., Armonk, New York, USA). According to the data distribution, continuous data are presented as the mean (standard deviation or standard error mean) or median (interquartile range). For multiple comparisons, one-way ANOVA was used to define mean differences of glucose response between groups with Bonferroni posthoc test. Two-way repeated measure Table 2. Bodyweight and food intake of rats

\begin{tabular}{lcc}
\hline \multicolumn{1}{c}{ Rats } & Bodyweight $(\mathrm{g})$ & $\begin{array}{c}24 \text { hrs food intake } \\
(\mathrm{g} / 24 \mathrm{hrs})\end{array}$ \\
\hline Control $(\mathrm{n}=6)$ & $335.70 \pm 46.64^{\mathrm{a}}$ & $29.07 \pm 0.59^{\mathrm{a}}$ \\
Durian $(\mathrm{n}=6)$ & $349.67 \pm 45.72^{\mathrm{a}}$ & $29.05 \pm 0.22^{\mathrm{a}}$ \\
$\beta$-Glucan $(\mathrm{n}=7)$ & $335.78 \pm 28.45^{\mathrm{a}}$ & $27.36 \pm 0.97^{\mathrm{a}}$ \\
Durian $+\beta$-Glucan $(\mathrm{n}=8)$ & $351.22 \pm 31.45^{\mathrm{a}}$ & $22.60 \pm 0.79^{\mathrm{b}}$ \\
\hline
\end{tabular}

Values are expressed as mean \pm standard deviation for body weight and mean \pm standard error mean for $24 \mathrm{hrs}$ food intake. Values with different superscripts are significantly $(p<0.05)$ different within the same column.

ANOVA was used to compare the differences in glucose response at different time points. Non-parametric Kruskal-Wallis test was used to compare the median of food intakes and incremental area under the curve among groups with Mann-Whitney test for multiple comparisons.

\section{Results}

\subsection{Baseline body weight and changes in food intake}

Table 2 shows baseline characteristics of the experimental rats. Bodyweight was in the range of 335.70 (46.64) to 351.22 (31.45) g. Median daily food intake was significantly lower in Durian $+\beta$-glucan compared to other groups (Table 2$)(p=0.008)$.

\subsection{Postprandial glycaemic response}

The total polyphenols content of durian (D24 variety) was 131.40 (22.20) $\mathrm{mg} \mathrm{GAE} / 100 \mathrm{~g}$ fresh weight. Table 3 and Figure 1 show the mean postprandial glycaemic response at different time points. The durian group showed a significantly lower postprandial glucose at 30,60 and 90 mins with $8.35 \mathrm{mmol} / \mathrm{L}(p=0.028)$, $7.82 \mathrm{mmol} / \mathrm{L}(p=0.014)$ and $8.00 \mathrm{mmol} / \mathrm{L}(p=0.042)$ compared with control with $12.08 \mathrm{mmol} / \mathrm{L}, 10.28 \mathrm{mmol} /$

Table 3. Glucose Response from 0 to $120 \mathrm{mins}$

\begin{tabular}{ccccc}
\hline \multicolumn{5}{c}{ Blood glucose level (mmol/L) } \\
\hline Time (mins) & $\begin{array}{c}\text { Control } \\
(\mathrm{n}=6)\end{array}$ & $\begin{array}{c}\text { Durian } \\
(\mathrm{n}=6)\end{array}$ & $\begin{array}{c}\beta \text {-Glucan } \\
(\mathrm{n}=7)\end{array}$ & $\begin{array}{c}\text { Durian }+\beta \text {-Glucan } \\
(\mathrm{n}=8)\end{array}$ \\
\hline 0 & $7.47 \pm 0.18^{\mathrm{a}}$ & $6.50 \pm 0.12^{\mathrm{a}}$ & $6.53 \pm 0.23^{\mathrm{a}}$ & $6.56 \pm 0.29^{\mathrm{a}}$ \\
15 & $12.00 \pm 1.00^{\mathrm{a},{ }^{*}}$ & $10.03 \pm 0.75^{\mathrm{a}}$ & $10.31 \pm 0.86^{\mathrm{a}}$ & $10.61 \pm 0.62^{\mathrm{a},{ }^{* *}}$ \\
30 & $12.08 \pm 1.24^{\mathrm{a}}$ & $8.35 \pm 0.56^{\mathrm{b}}$ & $10.03 \pm 0.36^{\mathrm{a}, \mathrm{b}, *}$ & $9.38 \pm 0.82^{\mathrm{a}^{\mathrm{b}, \mathrm{b}}}$ \\
60 & $10.28 \pm 0.73^{\mathrm{a}}$ & $7.82 \pm 0.49^{\mathrm{b}}$ & $8.80 \pm 0.37^{\mathrm{a}, \mathrm{b}, *, * *}$ & $8.19 \pm 0.35^{\mathrm{b}, * *}$ \\
90 & $9.63 \pm 0.20^{\mathrm{a}}$ & $8.00 \pm 0.54^{\mathrm{b}}$ & $8.67 \pm 0.34^{\mathrm{a}, \mathrm{b}, *, * *}$ & $7.99 \pm 0.33^{\mathrm{b}, * *}$ \\
120 & $10.00 \pm 0.39^{\mathrm{a}, *}$ & $8.10 \pm 0.39^{\mathrm{b}}$ & $9.51 \pm 0.17^{\mathrm{a}, \mathrm{b}, *}$ & $8.34 \pm 0.32^{\mathrm{b}}$ \\
\hline
\end{tabular}

Values are expressed as mean \pm standard error mean.

Values with different superscripts are significantly $(\mathrm{p}<0.05)$ different within the same row.

*Significant differences between fasting ( 0 mins) with other time points (within column).

**Significant difference between 15 mins with other time points (within column). 

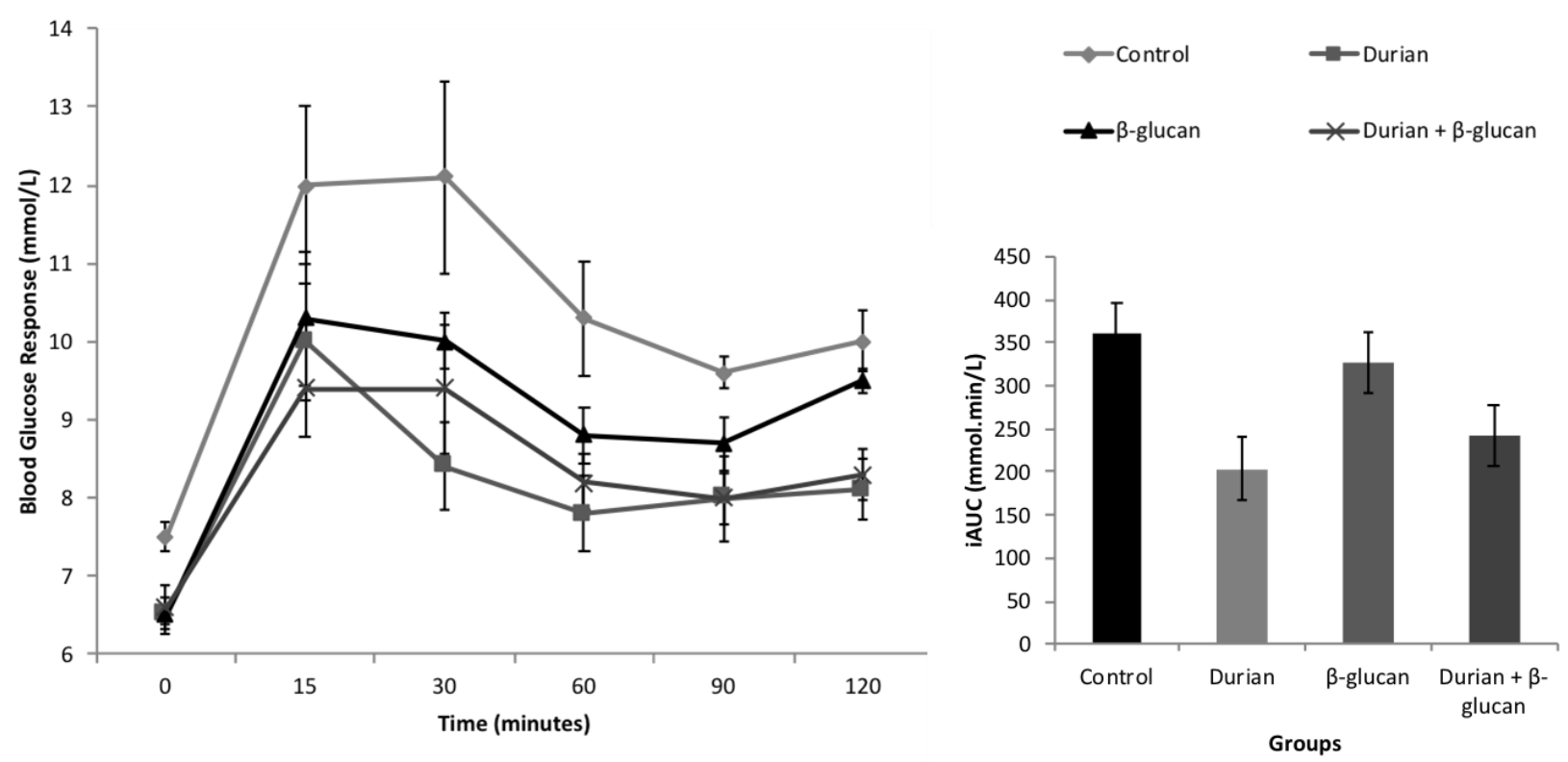

Figure 1. Mean glucose response and iAUC of all groups. Values are expressed as mean $\pm \operatorname{SEM}(n=6-8)$. iAUC: incremental area under the curve

$\mathrm{L}$ and $9.63 \mathrm{mmol} / \mathrm{L}$, respectively. The durian group showed a significantly lower glucose response at 120 mins with $8.10 \mathrm{mmol} / \mathrm{L}(p=0.004,0.036)$ compared with the control and $\beta$-glucan with $10.00 \mathrm{mmol} / \mathrm{L}$ and $9.51 \mathrm{mmol} / \mathrm{L}$, respectively. The durian $+\beta$-glucan group showed significantly lower glucose responses at 60, 90 and $120 \mathrm{mins}$ with $8.19 \mathrm{mmol} / \mathrm{L}(p=0.029), 7.99 \mathrm{mmol} / \mathrm{L}$ $(p=0.024)$ and $8.34 \mathrm{mmol} / \mathrm{L}(p=0.008)$, respectively compared with control $(10.28 \mathrm{mmol} / \mathrm{L}, 9.63 \mathrm{mmol} / \mathrm{L}$ and $10.00 \mathrm{mmol} / \mathrm{L}$, respectively). However, there was no statistical difference between groups $(p>0.05)$ for iAUC.

There were significant differences between 0 (fasting) with 15 and 120 mins for control. There were no significant differences in blood glucose level at different time points in the durian group. There were significant differences between 0 (fasting) and other time points except at 15 mins for the $\beta$-glucan group and also between 15 mins with 60 and 90 mins. The durian $+\beta-$ glucan group showed significant differences between 0 (fasting) at 15 and 30 mins and also between 15 mins and 60 mins, and between 15 mins and 90 mins.

\section{Discussion}

The total polyphenols content (TPC) of Malaysian durian variety D24 was 131.40 (22.20) $\mathrm{mg}$ GAE/100 g fresh weight. The TPC was higher than in other Malaysian varieties such Chaer Phoy $(67.12 \mathrm{mg}$ GAE/100 g FW), Durian D11 (71.13 mg GAE/100 g FW), Durian Yah Kang (80.45 mg GAE/100 g FW) and Durian Ang Jin (97.78 mg GAE/100 g FW) and also higher than in four Thai varieties $(26.44-112.17 \mathrm{mg}$ GAE/100 g FW) (Ashraf et al., 2011; Charoenkiatkul et al., 2015). TPC content is especially high in the Monthong variety (360 mg GAE/100 g FW) (Ashraf et al., 2011). TPC varies, however, with factors such as ripening and ripe durian showed higher total polyphenol content than merely mature durian (Arancibia-Avila et al., 2008). Other factors such as altitude also affect fruit quality and polyphenol content, possibly due to variations in ultraviolet light intensity, day length, and temperature (Jaakola and Hohtola, 2010).

The next aim was to determine the effects of durian, $\beta$-glucan and durian $+\beta$-glucan on food intake and blood glucose response in rats. Previous meta-analysis showed a significant reduction in the energy intake of individual $\beta$-glucan and there was a small to medium and nonsignificant effect size of $\beta$-glucan either in the liquid or solid food matrix on energy intake (Salleh et al., 2019). In our animal study, a combination of durian and $\beta$ glucan significantly $(p=0.008)$ reduced $24 \mathrm{~h}$ food intake compared with other groups. The effects could be mediated by the released of satiety hormones. Satiety hormones could play a role in reduced hunger and positively reduced food intake (Lawley and Walker, 2005). Ghrelin is one of the gut hormones secreted from the stomach that stimulates food intake (Wren et al., 2001). Cholecystokinin (CCK), peptide YY (PYY) and glucagon-like peptide (GLP-1) are released from the intestine and might inhibit food intake through the gutbrain axis (Walker et al., 2005). Gut hormones could be stimulated by substances such as short-chain fatty acids (SCFA) (Canfora et al., 2015). The effect of fibre on satiety depends on its physicochemical properties and physiological effects in the GI tract (van Kleef et al., 2011; Wanders et al., 2011).

Viscous fibres are likely to be more effective in promoting satiation. When $\beta$-glucan is consumed, it will form a highly viscous solution in the stomach and small 
intestine, stimulates gastric distension, slows down the gastric emptying and affects the levels of gut hormones involved in appetite and satiety (Juvonen et al., 2009; Kristensen and Jensen, 2011). Slowing the rate of food ingestion resulted in delayed activation of mechanoreceptors and chemoreceptors in the gastrointestinal tract, which could prolong satiety (Janssen et al., 2011; Chambers, Morrison and Frost, 2015). High molecular weight barley $\beta$-glucan with increased viscosity has been reported to attenuate glycaemic response, gastric emptying and in vitro starch digestion (Thondre et al., 2013). Carlson et al. (2017) showed that both Oatwell (containing $22 \%$ oat $\beta$-Glucan) and pure $\beta$-glucan significantly $(p<0.05)$ increased propionate concentrations after $12 \mathrm{hrs}$ of fermentation with maximum concentration attained at $24 \mathrm{hrs}$, compared with control fibres (xylooligosaccharides, whole fibre mixtures and pure inulin) (Carlson et al., 2017). Another study showed increased SCFA levels (2methyl-propanoic, acetate, butyrate, and propionate) after 2 months of barley $\beta$-glucan treatment in healthy subjects (Angelis et al., 2015). Another study supplemented inulin-propionate ester in a randomized, double-blind, placebo-controlled study in fifty healthy volunteers for 24 weeks. The supplementation increased postprandial PYY and GLP-1 levels and reduced overall energy intake (Chambers et al., 2015).

A study by Miyamoto et al. (2018) showed barley $\beta$ glucan $(0.6 \%$ to $2.0 \%)$ increased PYY and GLP-1 and subsequently suppressed appetite and improved insulin sensitivity in mice fed with a high-fat diet. The supplementation significantly $(p<0.05)$ increased acetate and propionate production in the colon compared with control. This could be due to a significant increase in the number of Actinobacteria in the colon (Miyamoto et al., 2018). Actinobacteria is one of the saccharolytic bacteria in the gut that is able to ferment soluble $\beta$-glucan to produce SFCA (Chakraborti, 2015; Binda et al., 2018).

Durian contains ethyl propionate, methyl propionate and propyl propionate (A Aziz and Mhd Jalil, 2019). Hence, a combination of durian and $\beta$-glucan might have additional effects on SCFA production and possibly also on blood glucose response. This study showed that a combination of durian and $\beta$-glucan significantly $(p<0.05)$ reduced glucose levels at 60, 90 and $120 \mathrm{mins}$ compared with control. Rats supplemented with durian showed significantly $(p<0.05)$ reduced glucose levels at 30, 60 and 90 mins compared with control. Durian is rich in fat and sugars but showed significantly lower glycaemic index (GI) in humans compared with other tropical fruits, specifically watermelon, papaya and pineapple (Robert et al., 2008). Durian's low GI values might be due to its high fibre and fat content. Fat and sugar contents are in the range of 1.6 to $5.3 \mathrm{~g}$ per $100 \mathrm{~g}$ fresh weight and 8 to $20 \mathrm{~g}$ per $100 \mathrm{~g}$ fresh weight, respectively in different durian varieties (A Aziz and Mhd Jalil, 2019). Fat has no direct effect on blood glucose response but could delay gastric emptying and subsequently slow the rate of glucose absorption (Hu et al., 2001). Another study showed that supplementation with the Monthong durian variety (5\% freeze-dried) reduced plasma glucose in cholesterol-enriched diets compared with control (Leontowicz et al., 2007). Durian is rich in potassium in the range of 70 to $600 \mathrm{mg}$ per $100 \mathrm{~g}$ fresh weight, comparable to potassium-rich banana (A Aziz and Mhd Jalil, 2019). A meta-analysis and systematic review by Carter et al. (2010) suggested a significant association of a higher intake of potassiumrich green leafy vegetables with lower risk of diabetes (Carter et al., 2010). A recent experimental study showed that potassium chloride $(\mathrm{KCl})$ supplementation improved fasting glucose levels in African Americans with prediabetes (Chatterjee et al., 2017). However, there were no significant effects on glucose and insulin levels. Another explanation may be the presence of polyphenols. A recent review showed total polyphenol content (TPC) in the range of 21 to $283 \mathrm{mg} / 100 \mathrm{~g}$ fresh weight (A Aziz and Mhd Jalil, 2019). In the present study, TPC of durian was $131 \mathrm{mg} / 100 \mathrm{~g}$ fresh weight. Kim et al. (2016) showed that polyphenol-rich beverages (coffee, tea and chocolate) and fruits could inhibit $\alpha$ amylase and glucosidase, inhibit glucose absorption in the intestine and reduce hepatic glucose output (Kim et al., 2016). Hence, in this study, we proposed that potassium and polyphenols in durian could play a role in controlling blood glucose. However, this needs further investigation in animal or human studies.

This study showed that a combination of $\beta$-glucan with durian rather than $\beta$-glucan per se was more effective in reducing blood glucose level. High viscosity $\beta$-glucan effectively decreased glucose response compared with the low viscosity (Panahi et al., 2007; Juvonen et al., 2009). Viscosity of $\beta$-glucan depends on its molecular weight and food sources (e.g. barley, oats, mushroom) (Panahi et al., 2007; Cleary et al., 2007). A review by Tosh (2013) showed that $76 \%$ of treatments from a variety of processed foods containing $4 \mathrm{~g}$ of oat or barley $\beta$-glucan significantly reduced glycaemic response. This was in line with the European Food Safety Authority's recommendation of $4 \mathrm{~g}$ of $\beta$-glucan (either oats or barley) per $30 \mathrm{~g}$ available carbohydrate to reduce blood glucose response without adversely increasing insulin response (EFSA, 2011). In this study, however, we failed to observe any significant changes in blood glucose response for the $\beta$-glucan group. The purity of $\beta$-glucan used was $20 \%$ which could partly explain the observed outcome. However, this study 
suggests that durian reduced blood glucose response and combination of $\beta$-glucan with durian reduced food intake. Further in vivo study with higher purity of $\beta$ glucan with defatted durian should be investigated in more detail.

\section{Conflicts of interest}

The authors declare no conflict of interest. The sponsor had no role in the design of the study; in the collection, analyses, or interpretation of data; in the writing of the manuscript, and in the decision to publish the results.

\section{Acknowledgements}

This study and the Article Processing Charge (APC) were funded by the Fundamental Research Grant Scheme (FRGS) Ministry of Education Malaysia (grant number: FRGS/1/2017/SKK06/UNISZA/03/07).

\section{References}

A Aziz, N.A. and Mhd Jalil, A.M. (2019). Bioactive compounds, nutritional value, and potential health benefits of indigenous durian (Durio Zibethinus Murr.): A review. Foods, 8(3), 5-22. https:// doi.org/10.3390/foods 8030096

Angelis, M. De., Montemurno, E., Vannini, L., Cosola, C., Cavallo, N., Gozzi, G., Maranzano, V., Cagno, R.Di., Gobbetti, M. and Gesualdo, L. (2015). Effect of whole-grain barley on the human fecal microbiota and metabolome. Applied and Environmental Microbiology, 81, 7945-7956. https:// doi.org/10.1128/AEM.02507-15

Arancibia-Avila, P., Toledo, F., Park, Y.S., Jung, S.T., Kang, S.G., Heo, B.G., Lee, S.H., Sajewicz, M., Kowalska, T. and Gorinstein, S. (2008). Antioxidant properties of durian fruit as influenced by ripening. LWT-Food Science and Technology, 41(10), 21182125. https://doi.org/10.1016/j.lwt.2007.12.001

Ashraf, M.A., Maah, M.J. and Yusoff, I. (2011). Study of antioxidant potential of tropical fruit durian. Asian Journal of Chemistry, 23(8), 3357-3361.

Binda, C., Lopetuso, L.R., Rizzatti, G., Gibiino, G., Cennamo, V. and Gasbarrini, A. (2018). Actinobacteria: A relevant minority for the maintenance of gut homeostasis. Digestive and Liver Disease, 50(5), 421-428. https://doi.org/10.1016/ j.dld.2018.02.012

Canfora, E.E., Jocken, J.W. and Blaak, E.E. (2015). Short-chain fatty acids in control of body. Nature Reviews Endocrinology, 11, 577-591. https:// doi.org/10.1038/nrendo.2015.128
Carlson, J.L., Erickson, J.M., Hess, J.M., Gould, T.J. and Slavin, J.L. (2017). Prebiotic dietary fiber and gut health: comparing the in vitro fermentations of betaglucan. Nutrients, 9(12), 1-17. https:// doi.org/10.3390/nu9121361

Carter, P., Gray, L.J., Troughton, J., Khunti, K. and Davies, M.J. (2010). Fruit and vegetable intake and incidence of type 2 diabetes mellitus: systematic review and meta-analysis. The BMJ, 2010, 341. https://doi.org/10.1136/bmj.c4229

Chakraborti, C.K. (2015). New-found link between microbiota and obesity. World Journal of Gastrointestinal Pathophysiology, 6(4), 110-119. https://doi.org/10.4291/wjgp.v6.i4.110

Chambers, E.S., Viardot, A., Psichas, A., Morrison, D.J., Murphy, K.G., Zac-Varghese, S.E.K., MacDougall, K., Preston, T., Tedford, C., Finlayson, G.S., Blundell, J.E., Bell, J.D., Thomas, E.L., Mt-Isa, S., Ashby, D., Gibson, G.R., Kolida, S., Dhillo, W.S., Bloom, S.R., Morley, W., Clegg, S. and Frost, G. (2015). Effects of targeted delivery of propionate to the human colon on appetite regulation, body weight maintenance and adiposity in overweight adults. Gut, 64(11), 1744-1754. https://doi.org/10.1136/gutjnl2014-307913

Chambers, E.S., Morrison, D.J. and Frost, G. (2015). Control of appetite and energy intake by SCFA: what are the potential underlying mechanisms? Proceedings of the Nutrition Society, 74(3), 328336. https://doi.org/10.1017/S0029665114001657

Charoenkiatkul, S., Thiyajai, P. and Judprasong, K. (2015). Nutrients and bioactive compounds in popular and indigenous durian (Durio zibethinus murr.). Food Chemistry, 193, 181-186. https:// doi.org/10.1016/j.foodchem.2015.02.107

Chatterjee, R., Slentz, C., Davenport, C.A., Johnson, J., Lin, P., Muehlbauer, M., D’Alessio, D., Svetkey, L.P. and Edelman, D. (2017). Effects of potassium supplements on glucose metabolism in African Americans with prediabetes: a pilot trial. American Journal of Clinical Nutrition, 106(6), 1431-1438. https://doi.org/10.3945/ajcn.117.161570

Cleary, L.J., Andersson, R. and Brennan, C.S. (2007). The behaviour and susceptibility to degradation of high and low molecular weight barley $\beta$-glucan in wheat bread during baking and in vitro digestion. Food Chemistry, 102(3), 889-897. https:// doi.org/10.1016/j.foodchem.2006.06.027

Delaney, B., Nicolosi, R.J., Wilson, T.A., Carlson, T., Frazer, S., Zheng, G.H., Hess, R., Ostergen, K., Haworth, J. and Knutson, N. (2003). B-Glucan Fractions from Barley and Oats Are Similarly Antiatherogenic in Hypercholesterolemic Syrian 
Golden Hamsters. The Journal of Nutrition, 133(2), 468-475. https://doi.org/10.1093/jn/133.2.468

European Food Safety Authority (EFSA). (2011). Scientific Opinion on the substantiation of health claims related to beta-glucans from oats and barley and maintenance of normal blood LDL-cholesterol concentrations (ID 1236, 1299), increase in satiety leading to a reduction in energy intake (ID 851, 852), reduction of post-prandial glycaemic responses (ID 821,824 ), and "digestive function" (ID 850) pursuant to Article 13(1) of Regulation (EC) No 1924/2006. EFSA Journal, 9(6), 1-21. https:// doi.org/10.2903/j.efsa.2011.2207

Hartvigsen, M.L., Gregersen, S., Lærke, H.N., Holst, J.J., Knudsen, K.E.B. and Hermansen, K. (2014). Effects of concentrated arabinoxylan and $\beta$-glucan compared with refined wheat and whole grain rye on glucose and appetite in subjects with the metabolic syndrome : a randomized study. European Journal of Clinical Nutrition, 68, 84-90. https:// doi.org/10.1038/ejen.2013.236

Ho, L.H. and Bhat, R. (2015). Exploring the potential nutraceutical values of durian (Durio zibethinus L.) An exotic tropical fruit. Food Chemistry, 168, 80 89. https://doi.org/10.1016/j.foodchem.2014.07.020

Hu, F.B., Dam, R.M.V. and Liu, S. (2001). Diet and risk of Type II diabetes: the role of types of fat and carbohydrate. Diabetologia, 44, 805-817. https:// doi.org/10.1007/s001250100547

Huang, X.F., Yu, Y., Beck, E.J., South, T., Li, Y., Batterham, M.J., Tapsell, L.C. and Chen, J. (2011). Diet high in oat $\beta$-glucan activates the guthypothalamic (PYY 3 - 36 -NPY) axis and increases satiety in diet-induced obesity in mice. Molecular Nutrition and Food Research, 55(7), 1118-1121. https://doi.org/10.1002/mnfr.201100095

Jaakola, L. and Hohtola, A. (2010). Effect of latitude on flavonoid biosynthesis in plants. Plant Cell and Environment, 33(8), 1239-1247. https:// doi.org/10.1111/j.1365-3040.2010.02154.x

Janssen, P., Berghe, P.V., Verschueren, S., Lehmann, A., Depoortere, I. and Tack, J. (2011). Review article: The role of gastric motility in the control of food intake. Alimentary Pharmacology and Therapeutics, 33(8), 880-894. https://doi.org/10.1111/j.13652036.2011.04609.x

Juvonen, K.R., Purhonen, A.K., Salmenkallio-Marttila, M., Lahteenmaki, L., Laaksonen, D.E., Herzig, K.H., Uusitupa, M.I.J., Poutanen, K.S. and Karhunen, L.J. (2009). Viscosity of Oat Bran-Enriched Beverages Influences Gastrointestinal Hormonal Responses in Healthy Humans. The Journal of Nutrition, 139(3), 461-466. https://doi.org/10.3945/jn.108.099945
Kerckhoffs, D.A.J.M., Hornstra, G. and Mensink, R.P. (2003). Cholesterol-lowering effect of $\beta$-glucan from oat bran in mildly hypercholesterolemic subjects may decrease when $\beta$-glucan is incorporated into bread and cookies. American Journal of Clinical Nutrition, 78(2), 221-227. https://doi.org/10.1093/ ajen/78.2.221

Kim, Y., Keogh, J.B. and Clifton, P.M. (2016). Polyphenols and Glycaemic Control. Nutrients, 8(1), 1-27. https://doi.org/10.3390/nu8010017

Kristensen, M. and Jensen, M.G. (2011). Dietary fibres in the regulation of appetite and food intake. Importance of viscosity. Appetite, 56(1), 65-70. https://doi.org/10.1016/j.appet.2010.11.147

Lawley, T.D. and Walker, A.W. (2012). Intestinal colonization resistance. Immunology, 138(1), 1-11. https://doi.org/10.1111/j.1365-2567.2012.03616.x

Leontowicz, H., Leontowicz, M., Haruenkit, R., Poovarodom, S., Jastrzebski, Z., Drzewiecki, J., Ayala, A.L.M., Jesion, I., Trakhtenberg, S. and Gorinstein, S. (2008). Durian (Durio zibethinus Murr.) cultivars as nutritional supplementation to rat's diets. Food and Chemical Toxicology, 46(2), 581-589. https://doi.org/10.1016/j.fct.2007.08.042

Leontowicz, H., Leontowicz, M., Jesion, I., Bielecki, W., Poovarodom, S., Vearasilp, S., Gonzalez-Aguilar, G., Robles-Sanchez, M., Trakhtenberg, S. and Gorinstein, S. (2011). Positive effects of durian fruit at different stages of ripening on the hearts and livers of rats fed diets high in cholesterol. European Journal of Integrative Medicine, 3(3), e169-e181. https://doi.org/10.1016/j.eujim.2011.08.005

Leontowicz, M., Leontowicz, H., Jastrzebski, Z., Jesion, I., Haruenkit, R., Poovarodom, S., Katrich, E., Tashma, Z., Drzewiecki, J., Trakhtenberg, S. and Gorinstein, S. (2007). The nutritional and metabolic indices in rats fed cholesterol-containing diets supplemented with durian at different stages of ripening. BioFactors, 29(2-3), 123-136. https:// doi.org/10.1002/biof.552029203

Luscombe-Marsh, N.D., Seimon, R.V., Bollmeyer, E., Wishart, J.M., Wittert, G.A., Horowitz, M., Bellon, M. and Feinle-Bisset, C. (2013). Acute effects of oral preloads with increasing energy density on gastric emptying, gut hormone release, thermogenesis and energy intake, in overweight and obese men. Asia Pacific Journal of Clinical Nutrition, 22(3), 380-390.

Lutz, M, Hernández, J. and Henríquez, C. (2015). Phenolic content and antioxidant capacity in fresh and dry fruits and vegetables grown in Chile. CyTAJournal of Food, 13(4), 541-547. 
Marathe, C.S., Marathe, J.A., Rayner, C.K., Kar, P., Jones, K.L. and Horowitz, M. (2019). Hypoglycaemia and Gastric Emptying. Diabetes, Obesity and Metabolism, 21(3), 491-498. https:// doi.org/10.1111/dom.13570

Mat Amin, A., Ahmad, A.S., Yin, Y.Y., Yahya, N. and Ibrahim, N. (2007). Extraction, purification and characterization of durian (Durio zibethinus) seed gum. Food Hydrocolloids, 21(2), 273-279. https:// doi.org/10.1016/j.foodhyd.2006.04.004

Miyamoto, J., Watanabe, K., Taira, S., Kasubuchi, M., Li, X. and Irie, J. (2018). Barley $\beta$-glucan improves metabolic condition via short-chain fatty acids produced by gut microbial fermentation in high fat diet fed mice. PLOS ONE, 13, e0196579. https:// doi.org/10.1371/journal.pone.0196579

Nair, A.B. and Jacob, S. (2016). A simple practice guide for dose conversion between animals and human. Journal of Basic and Clinical Pharmacy, 7(2), 2731. https://doi.org/10.4103/0976-0105.177703

Nishimura, K., Hiramatsu, K., Watanabe, T. and Kita, K. (2017). Glucagon-like peptide-1 is co-localized with neurotensin in the chicken ileum. Cell and Tissue Research, 368, 277-286. https://doi.org/10.1007/ s00441-016-2561-0

Panahi, S., Ezatagha, A., Temelli, F., Vasanthan, T. and Vuksan, V. (2007). $\beta$-Glucan from two sources of oat concentrates affect postprandial glycemia in relation to the level of viscosity. Journal of American College of Nutrition, 26(6), 639-644. https://doi.org/10.1080/07315724.2007.10719641

Phillips, L.K., Deane, A.M., Jones, K.L., Rayner, C.K. and Horowitz, M. (2015). Gastric emptying and glycaemia in health and diabetes mellitus. Nature Reviews Endocrinology, 11, 112-128. https:// doi.org/10.1038/nrendo.2014.202

Robert, S.D., Ismail, A.A., Winn, T. and Wolever, T. (2008). Glycaemic index of common Malaysian fruits. Asia Pacific Journal of Clinical Nutrition, 17 (1), 35-39.

Salleh, S.N., Fairus, A.A.H., Zahary, M.N., Raj, N.B. and Mhd Jalil, A.M. (2019). Unravelling the effects of soluble dietary fibre supplementation on energy intake and perceived satiety in healthy adults: Evidence from systematic review and meta-analysis of randomised-controlled trials. Foods, 8(1), 1-22. https://doi.org/10.3390/foods8010015

Singleton, V.L., Orthofer, R., Lamuela-Raventos, R.M. (1999). Analysis of total phenols and other oxidation substrates and antioxidants by means of FolinCiocalteu reagent. Methods in Enzymology, 299, 152 -178. https://doi.org/10.1016/S0076-6879(99)990171
Theuwissen, E. and Mensink, R.P. (2008) Water-soluble dietary fibers and cardiovascular disease. Physiology and Behavior, 94(2), 285-292. https:// doi.org/10.1016/j.physbeh.2008.01.001

Thondre, P.S., Shafat, A. and Clegg, M.E. (2013). Molecular weight of barley $\beta$-glucan influences energy expenditure, gastric emptying and glycaemic response in human subjects. British Journal of Nutrition, 110(12), 2173-2179. https:// doi.org/10.1017/S0007114513001682

Tosh, S.M (2013). Review of human studies investigating the post-prandial blood-glucose lowering ability of oat and barley food products. European Journal of Clinical Nutrition, 67, 310317. https://doi.org/10.1038/ejen.2013.25

U.S. Food and Drug Administration (USFDA). (2005). Guidance for Industry: Estimating the Maximum Safe Starting Dose in Adult Healthy Volunteer. Retrieved on November 17, 2019 from USFDA Website: https://www.fda.gov/regulatoryinformation/search-fda-guidance-documents/ estimating-maximum-safe-starting-dose-initialclinical-trials-therapeutics-adult-healthy-volunteers.

van Kleef, E., van, Trijp, J.C.M., van den Borne, J.J.G.C. and Zondervan, C. (2011). Successful development of satiety enhancing food products: towards a multidisciplinary agenda of research challenges. Critical Reviews in Food Science and Nutrition, 52 (7), 611-628.

https:// doi.org/10.1080/10408398.2010.504901

Walker, A.W., Duncan, S.H., Leitch, E.C.M., Child, M.W. and Flint, H.J. (2005). pH and peptide supply can radically alter bacterial populations and shortchain fatty acid ratios within microbial communities from the human colon. Applied Environmental Microbiology, 71, 3692-3700. https:// doi.org/10.1128/AEM.71.7.3692-3700.2005

Wanders, A.J., van den Borne, J.J.G.C., de Graaf, C., Hulshof, T., Jonathan, M.C., Kristensen, M., Mars, M., Schols, H.A. and Feskens, E.J.M. (2011). Effects of dietary fibre on subjective appetite, energy intake and body weight: a systematic review of randomized controlled trials. Obesity Reviews, 12(9), 724-739. https://doi.org/10.1111/j.1467-789X.2011.00895.x

Wren, A.M., Seal, L.J., Cohen, M.A., Brynes, A.E., Frost, G.S., Murphy, K.G., Dhillo, W.S., Ghatei, M.A. and Bloom, S.R. (2001). Ghrelin enhances appetite and increases food intake in humans. The Journal of Clinical Endocrinology and Metabolism, 86(12), $5992 . \quad \mathrm{https} / / /$ doi.org/10.1210/ jcem.86.12.8111 